\title{
AUTORADIOGRAPHIC LOCALIZATION OF CEREBELLAR EXCITATORY AMINO ACID BINDING SITES IN THE MOUSE
}

\author{
J. M. M. Olson,* J. T. Greenamyre, $\$$ J. B. Penney $\$$ and A. B. Young $¥ \ddagger$ \\ Departments of Pharmacology and + Neurology, and the $\$$ Neuroscience Program, University of \\ Michigan, Ann Arbor, MI 48104. U.S.A.
}

\begin{abstract}
We have investigated the cellular localization of cerebellar excitatory amino acid binding sites in normal mice, in mice deficient in granule cells and, perhaps, stellate, basket and Golgi cells (granuloprival mice) and in mice lacking Purkinje cells. In the molecular layer of normal mouse cerebellum, the quisqualate-sensitive binding sites were the predominant type of excitatory amino acid receptor and there were relatively few $N$-methyl-D-aspartate or kainate-sensitive binding sites. The granule cell layer of normal mice contained a mixture of all 3 types, the $N$-methyl-D-aspartate-sensitive binding sites being predominant.

In the molecular layer of granuloprival mice, the number of quisqualate-sensitive binding sites was increased to $214 \%$ of control $(P<0.01)$, whereas $N$-methyl-D-aspartate-sensitive binding sites were decreased to $62 \%$ of control $(P<0.001)$ and kainate-sensitive binding sites were unchanged. In the granule cell layer of these mice, quisqualate-sensitive binding sites were increased to $200 \%(P<0.01)$, $N$-methyl-D-aspartate-sensitive binding sites were decreased to $47 \%(P<0.001)$ and kainate-sensitive binding sites were decreased to $49 \%(P<0.01)$ of their respective control values.

In the molecular layer of mice lacking Purkinje cells, quisqualate-sensitive binding sites were reduced to $29 \%(P<0.001)$ of control and $N$-methyl-D-aspartate-sensitive binding sites were unchanged. In the granule cell layer of these mice, neither quisqualate nor $N$-methyl-D-aspartate-sensitive binding sites were changed.

These results suggest that (1) quisqualate-sensitive binding sites are located principally on dendrites of Purkinje cells and that they up-regulate after deafferentation; (2) $N$-methyl-D-aspartate-sensitive binding sites are located on granule cells and, perhaps, stellate, basket and Golgi cells, and (3) kainate binding sites are located on cell bodies of granule and, perhaps, Golgi cells.
\end{abstract}

Glutamate, aspartate and perhaps some closely related compounds are thought to be major excitatory neurotransmitters in the central nervous system. ${ }^{15,32}$ The actions of these excitatory amino acids are mediated by at least three distinct receptors named for the selective agonists $N$-methyl-D-aspartate (NMDA), quisqualate (QA) and kainate (KA). ${ }^{36,31,52}$ The existence of multiple classes of binding sites, all of which bind glutamate, raises the possibility that each class of binding sites may have a distinct function and/or that each has a different neuronal or regional localization. Recently, autoradiographic methods have been developed to localize, characterize and quantify these binding sites. ${ }^{22,24,25,39}$

The cerebellar cortex is a convenient region in which to study excitatory amino acid binding sites because of its relatively simple, laminar cyto-

Address correspondence to: Anne B. Young, University of Michigan, Neuroscience Laboratory Building, 1103 East Huron Street, Ann Arbor, MI 48104, U.S.A.

Abbreviations: AP4,2-amino-4-phosphonobutyrate; GRN, granule cell layer; KA, kainate; MAM, methylazoxymethanol acetate; NMDA, $\boldsymbol{N}$-methyl-D-aspartate; QA, quisqualate. architecture, anatomically and physiologically defined circuitry and neurochemically defined cell types. In addition, there are selective mutations and cytotoxic drug treatments which render the cerebellum deficient in specific cell types, thereby altering cerebellar circuitry. Most importantly, it has been proposed that excitatory amino acids are the transmitters of the afferent climbing fibers, ${ }^{17,44,54}$ mossy fibers ${ }^{4,18}$ and the intrinsic granule cell/parallel fiber system. ${ }^{28,45,56}$ Thus, the dendrites of the Purkinje cells receive excitatory amino acid input from both the climbing fibers and the granule cell/parallel fiber system whereas the granule cells receive such input from the mossy fibers. In this study, using normal mice, granuloprival mice and mice lacking Purkinje cells, we have endeavored to determine the cellular localization of cerebellar NMDA-, QA- and KAsensitive binding sites by means of quantitative receptor autoradiography.

\section{EXPERIMENTAL PROCEDURES}

Animals

Granuloprival mice were produced by injecting pups of BLU-HA mice (Blue Spruce Farms, Albany, NY) with 
methylazoxymethanol (MAM, $30 \mathrm{mg} / \mathrm{kg}$ diluted to a concentration of $10 \mathrm{mg} / \mathrm{ml}$ in $0.9 \% \mathrm{NaCl}$ ) subcutaneously within hours of birth. MAM is a nucleic acid alkylating agent which kills cells undergoing mitosis at the time of drug distribution..$^{30}$ When injected on postnatal day 1 , this agent causes a selective depletion of granule, stellate, basket and Golgi cells in the mouse cerebellum. Binding experiments were performed in 42-day-old mice that had been treated as pups with MAM. Noninjected littermates were used as controls. Homozygous, recessive "nervous" mutant mice $(\mathrm{nr} / \mathrm{nr})$ which lack Purkinje cells ${ }^{32}$ were obtained from Jackson Laboratories (Bar Harbor, ME). Their neurologically normal littermates served as controls.

\section{Tissue preparation}

Mice were decapitated and their brains were rapidly removed. Cerebella and brainstems were dissected from forebrain, mounted on cryotome chucks with Lipohaw embedding matrix, and frozen under powdered dry ice. The mounted cerebella were warmed to $-20^{\circ} \mathrm{C}$ and $20 \mu \mathrm{m}$ sections were cut and thaw-mounted onto gelatin-coated slides. Tissue sections were washed in either $50 \mathrm{mM}$ Tris$\mathrm{HCl}$ containing $2.5 \mathrm{mM} \mathrm{CaCl}$ or $50 \mathrm{mM}$ Tris-acetate $\left(\mathrm{pH} 7.2\right.$ at $2^{\circ} \mathrm{C}$ ) for $30 \mathrm{~min}$ at $2^{\circ} \mathrm{C}$ to remove endogenous competitors and then were dried under a stream of room temperature air. The buffer used in this prewash (Tris-HCl or Tris-acetate) was always the same as that used in subsequent binding experiments and in the final rinse, as described below.

\section{Autoradiography}

A detailed description of the method for glutamate receptor autoradiography has been publiahod. 22,24,55 Briefly, in glutamate saturation studies, tissue sections were incubated with $30 \mathrm{nM}$ Lf'Hiflutemate (sp. act. $39 \mathrm{Ci} / \mathrm{mmol}$ ) and varying concentrations of unhbeled ghutamate ranging from $1 \mathrm{nM}$ to $10 \mu \mathrm{M}$ Tris- $\mathrm{HCl}$ containing $2.5 \mathrm{mM} \mathrm{CaCl}$ for $45 \mathrm{~min}$ at $2^{\circ} \mathrm{C}$. Nonspecific binding was determined in the presence of $1 \mathrm{mM}$ unlabeled glutamate and represented $<10 \%$ of total binding. Similar "blanks" were obtained with $1 \mathrm{mM}$ QA. Detailed competition studies were carried out in the presence of $200 \mathrm{nM}$ glutamate (sp. act. $4.5 \mathrm{Ci} / \mathrm{mmol}$ ) using a wide range of $\mathrm{QA}$ concentrations $1 \mathrm{nM}-1 \mathrm{mM})$ or NMDA concentrations (100 $\mathrm{nM}-1 \mathrm{mM})$. Previous studies have shown that QA displaces all epecific glutamate binding biphasically with $K, s$ for the high afinity and low affinity sites that differ by more than $10,000-$ fold. 22.24 The site with a low affinity for $Q A$ is equivalent to the NMDA sitc. ${ }^{22}$ QA biading site are defined, therefore, by their high affinity for QA in detailed competition curves using the LIGAND program to rosolve the sites as described previously. 2220,0 Similar results were obtained by defining QA sites as the specific plutamate binding sites remaining in the preance of $100 \mu \mathrm{M}$ NMDA or those specific binding sites dieplaced by $2.5 \mu \mathrm{M}$ QA. In analogous fashion, NMDA binding sites were defined as either those glutamate binding sites having a low affinity for QA in detailed competition curves or those sites remaining in the presence of $2.5 \mu \mathrm{M}$ QA. The glutamate binding assay did not measure kainate-sensitive sites because binding to these sites is inhibited by the calcium present in the assay buffer ${ }^{22,39}$ Kainate binding studies were carried out at $2^{\circ} \mathrm{C}$ with $\left.65 \mathrm{nM}{ }^{3} \mathrm{H}\right] \mathrm{kainate}$ (sp. act. $5 \mathrm{Ci} / \mathrm{mmol}$ ) in $50 \mathrm{mM}$ Trisacetate $(\mathrm{pH} 7.2)$ with various concentrations of unlabeled kainate (1 nM-100 $\mu \mathrm{M}$ ) for saturation studies. Nonspecific binding was determined in adjacent sections in the presence of either $1 \mathrm{mM}$ unlabeled glutamate or $100 \mu \mathrm{M}$ unlabeled kainate and represented $<5 \%$ of total binding.

After the incubation, sections were quickly rinsed 3 times with cold buffer, then rinsed once with cold $2.5 \%$ glutaraldehyde in acetone. The total rinse time was $<10 \mathrm{~s}$. Slides were blown dry with warm air, placed in $\mathrm{X}$-ray cassettes with appropriate radioactive standards and apposed to LKB Ultrofilm ${ }^{3} \mathrm{H} .{ }^{42}$ The film was exposed to the tissue sections for 14-21 days at $4^{\circ} \mathrm{C}$, then developed, fixed and dried. Tissue sections were then post-fixed with paraformaldehyde and stained with Cresyl Violet. Individual layers of cerebellum were identified on autoradiographs by comparison with the Cresyl Violet stained sections of the tissue that produced the film image. The optical densities of the film images were determined using a computer-assisted microdensitometer. ${ }^{10}$ Twenty or more readings from each layer of interest were averaged and the radioactivity of the underlying tissue determined by a computer-generated polynomial regression analysis which compared film densities produced by the tissue sections to those produced by the radioactive standards. ${ }^{42}$ All binding data were obtained by microdensitometry

\section{Data analysis}

Binding to the molecular and granule layers of MAMtreated mice was compared to that in untreatod littermates. Similarly, binding in homozygous "nervous" mutant mice lacking Purkinje cells was compared to neurologically normal littermates. Thus, MAM-treated and "nervous" mutant mice were compared to separate sets of control animals. Statistical analysis was by unpaired $t$-tests.

\section{RrguLTS}

\section{Histology}

In normal cerebellum the granule cell layer is characterized by a very dense collection of coll molei. The Purkinje cell layer is a monolayer of large neurons with pale nuclei located between the granule cell layer (GRN) and the molocular byer. The molecular layer has relatively few intrinaic neuron (badket and stellate celis) and the abundent vernopil conciats largely of granule cell axons and Parkiaje cell den-

Fig. 1. Nind-stained extions of control cerebellum (A), cerebeltum rendared deficiont in granule colls by

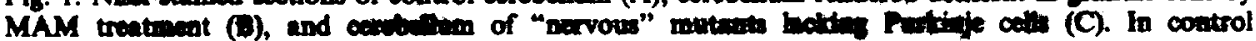

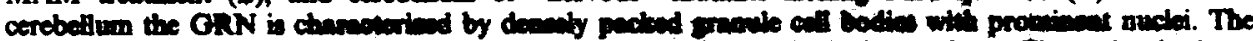

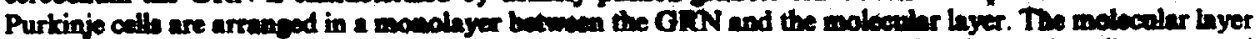

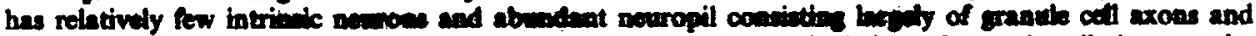

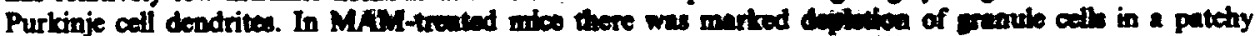

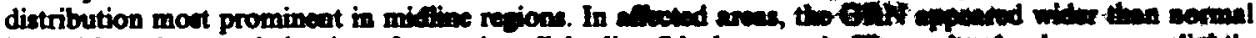

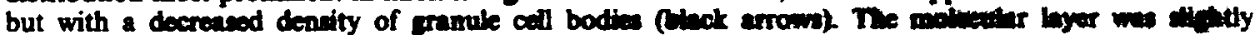

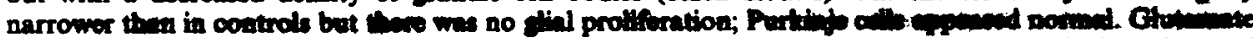

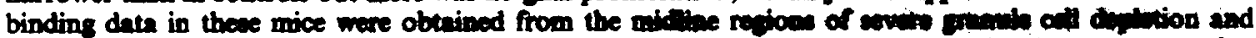
from adjecent areas of the molecular layer (wite arrom). In "norvoun" numat mioe there were very few

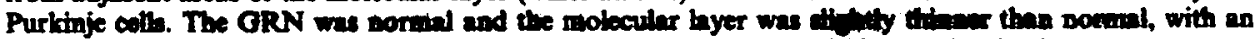
increace in the rohative density of Bergman astrocytes. MOL, molecular bayer. 

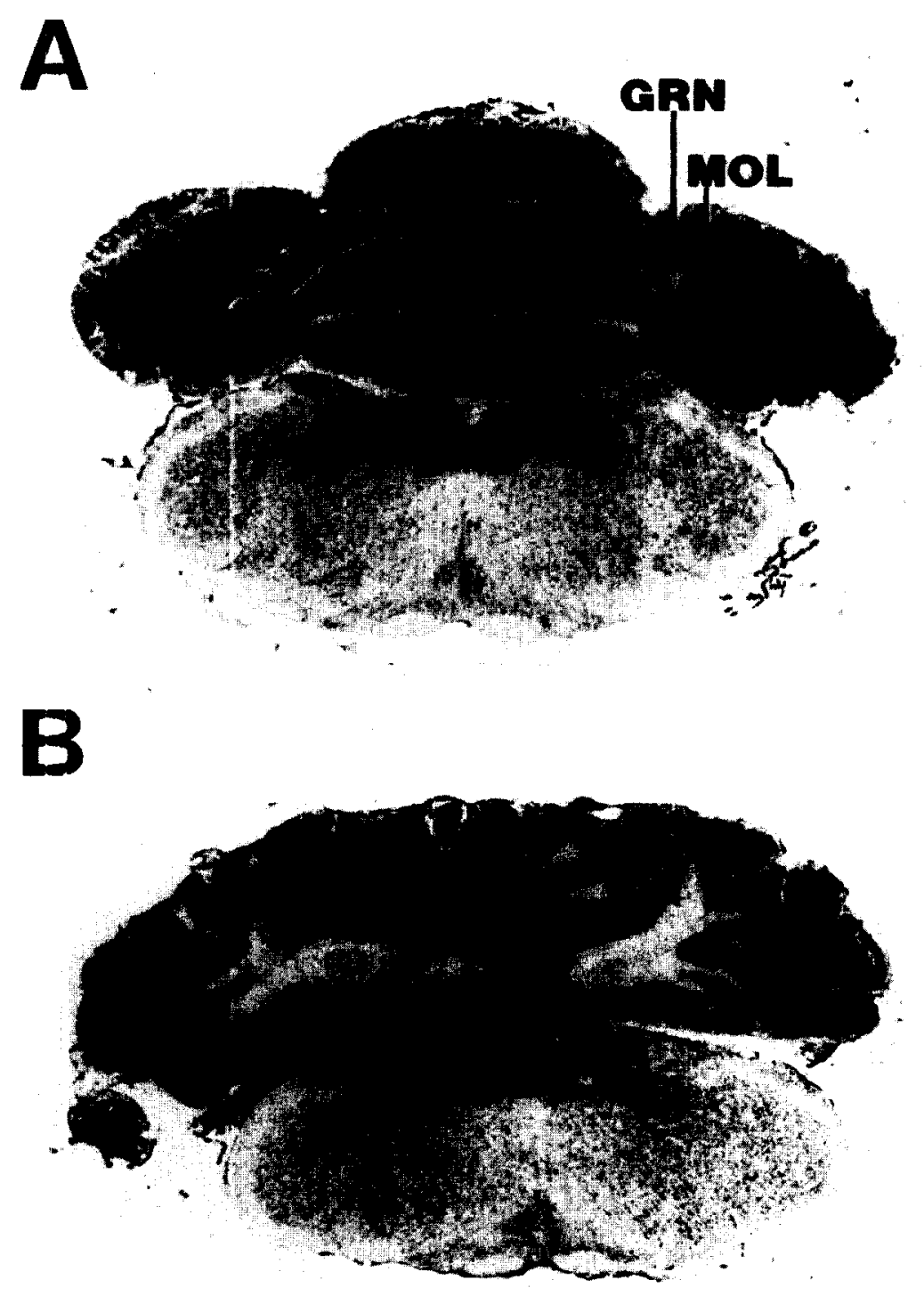

C

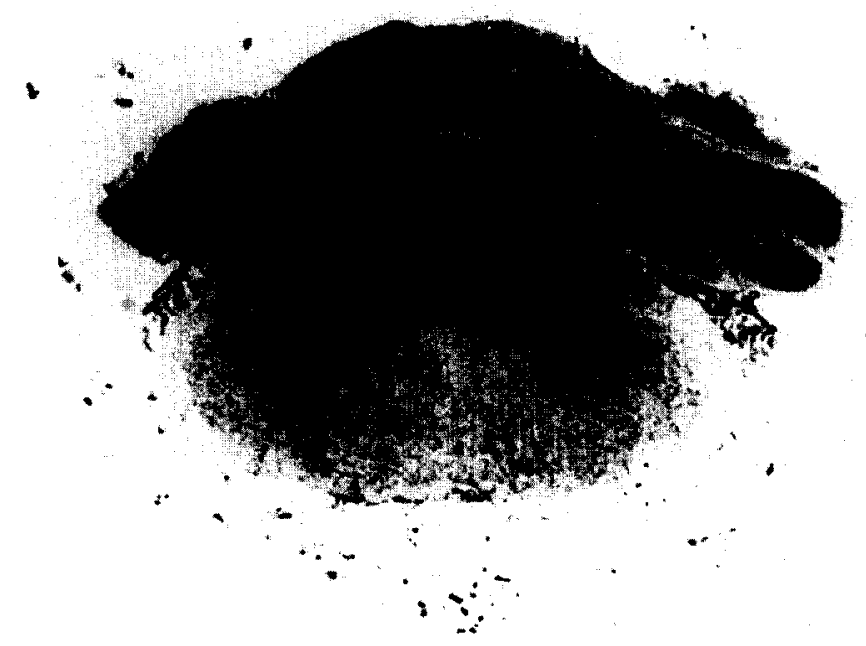

Fig. 1. 

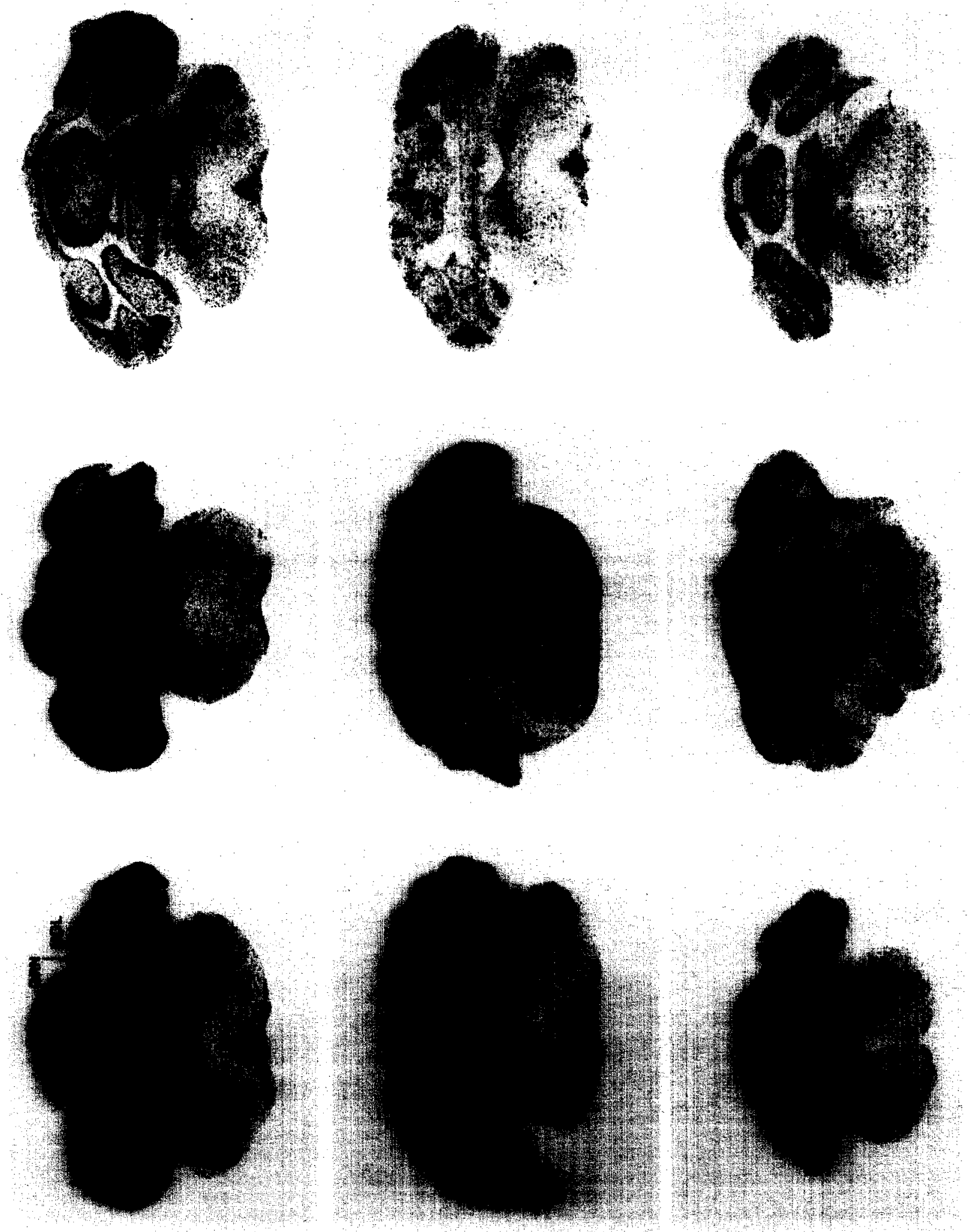
A

A TOTAL [ ${ }^{3} \mathrm{H}$ ] glUTAMATE BNDNG

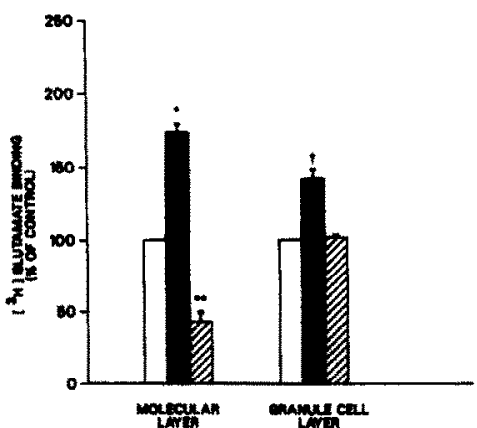

C

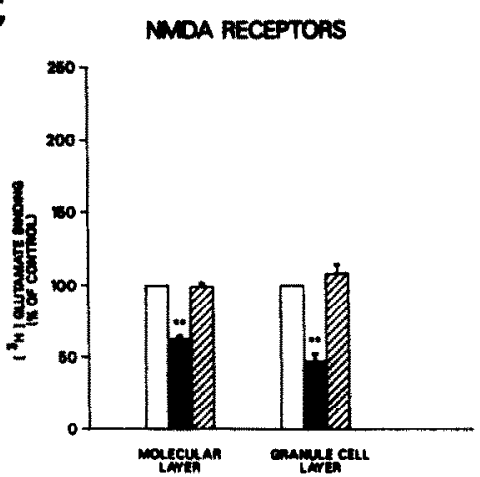

B

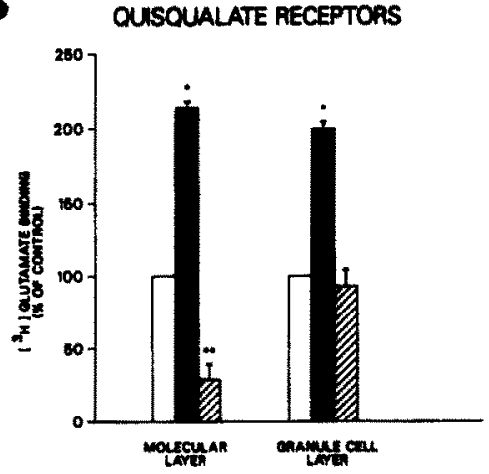

D

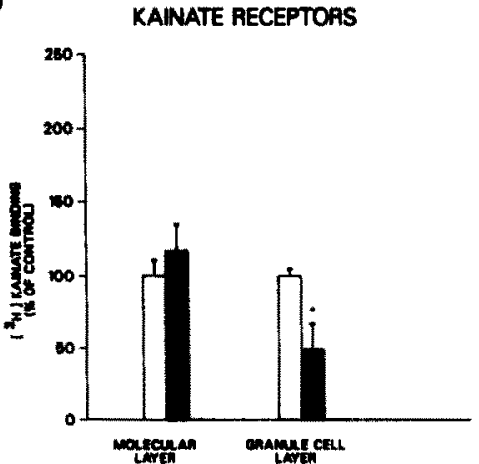

Fig. 3. Histograms of total glutamate binding (A), QA receptors (B), NMDA receptors (C) and KA binding (D) in the molecular layer and the GRN of granule cell-deficient mice (solid bars) and mice lacking Purkinje cells (striped bars) compared to controls (open bars). Data is presented as percentage of control values \pm S.E.M. In experiments represented by histograms $(A),(B)$ and $(C)$, separate sets of control animals were used for comparison with the MAM-treated and "nervous" mutants, as described under Experimental Procedures. Thus, control bars do not show standard error because they represent the level of binding (100\%) in two separate sets of control animals. In (D), control bars do show standard error because only data from MAM-treated mice and their controls are shown. Levels of significance $(† P<0.05, * P<0.01, * * P<0.001)$ were determined by comparison with appropriate controls by unpaired $t$-tests as described under Experimental Procedures. [ ${ }^{3}$ H]Glutamate concentration was $200 \mathrm{nM}$ $(A-C)$ and $\left[{ }^{3} \mathrm{H}\right]$ kainate concentration was $65 \mathrm{nM}$ (D).

drites (Fig. 1A). In the MAM-treated rats, there was a marked depletion of granule cells in a patchy distribution (Fig. 1B). The areas of granule cell depletion were most prominent in the midline regions and the damaged granule cell layer appeared wider than normal, but had a markedly decreased density of granule cell nuclei. The molecular layer was slightly narrower than in normal rats but had no increase in the number of glial cell nuclei. Purkinje cells in these animals appeared normal. In "nervous" mutant mice $(\mathrm{nr} / \mathrm{nr})$, there was a severe depletion of Purkinje cells. The GRN was normal, whereas the molecular layer was somewhat thinner than normal (Fig. 1C) with an increase in the relative density of Bergman astrocytes.

\section{Total glutamate binding}

At a $\left.{ }^{3} \mathrm{H}\right]$ glutamate concentration of $200 \mathrm{nM}$, total glutamate binding in control mice was higher in the molecular layer than in the GRN (5.55 vs $4.19 \mathrm{pmol} / \mathrm{mg}$ protein, respectively) (Figs 2 and 3). In MAM-treated mice, regions of severe granule cell depletion had increased levels of binding. At $200 \mathrm{nM}$, glutamate binding was increased to $174 \%$ of control in the molecular layer and to $140 \%$ in the GRN $(P<0.01$ and $P<0.05$, respectively). Saturation analysis in the molecular layer of control and MAMtreated mice (Fig. 4) revealed no significant difference in affinity of binding $\left(K_{D} s: 1.5 \pm 0.1\right.$ vs $1.5 \pm 0.4 \mu \mathrm{M}$, respectively) but a large increase in the number of

Fig. 2. Autoradiographs of total $\mathrm{L}-\left[{ }^{3} \mathrm{H}\right] \mathrm{glutamate}$ binding (left), QA receptors (center) and NMDA receptors (right) in control cerebellum (top row), granule cell-deficient cerebellum (middle row) and Purkinje cell-deficient cerebellum (bottom row). Black arrows mark areas of the GRN and white arrows mark areas of the molecular layer from which binding data were obtained. Receptor binding data are presented under Results and in Figs 3-5. MOL, molecular layer. 


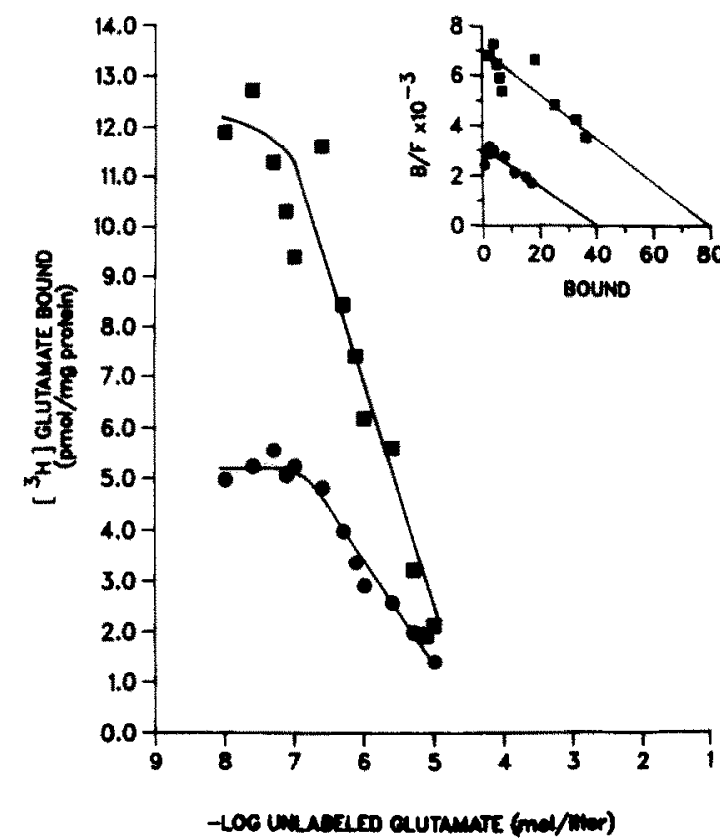

Fig. 4. Saturation andyais of $\mathrm{L}-[\mathrm{H} H$-lotenate bindion in the molecular kyer of control (circlex) ve thenle colloticient mice (equerow). Inet thows scatelend plots of the data. Saturation analysis was porformed as described under

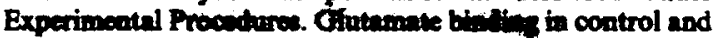
grunule cell-doficiont mice has the ame thity, but thore

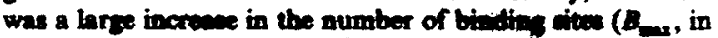

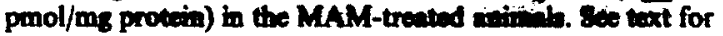
details.

binding sites in MAM-treated mice ( $B_{\text {mas }}: 43 \pm 3$ vs $91 \pm 20 \mathrm{pmol} / \mathrm{ms}$ protein, respoctively $P<0.01)$. In contrast, in the "nervous" mutant mice which lack Purkinje cells total glutamate binding was decreased to $43 \%$ of control in the molecular layer $(P<0.001)$ and was unchanged in the GRN.

\section{Quisqualate-sensitive binding sites}

In control mice, QA-sensitive binding sites (measured in the presence of $100 \mu \mathrm{M} \mathrm{NMDA}$ ) were almost three timos as numerous in the molccular byer as they were in the GRN (3.98 vs $1.40 \mathrm{pmol} / \mathrm{mg}$ protein, respectivaly) (Fis 2 and 3). Under the conditions of the binding aeary, QA-wendive binding sites account for about $75 \%$ of apecific tutanate binding sites in the molecular layor of control mice (Fig. 5 and Table 1). Only about $30 \%$ of GRN

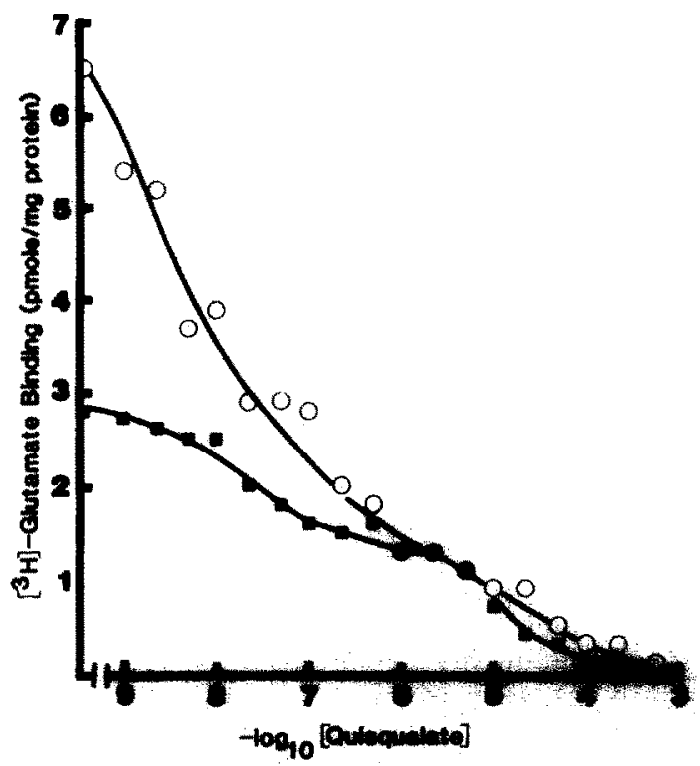

Fig. 5. Quiequalate competition curves in the malocelar

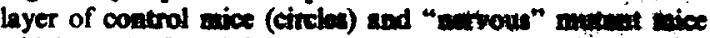

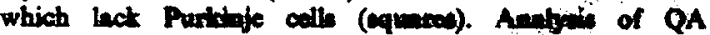

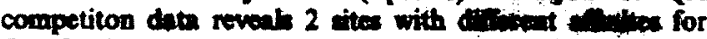

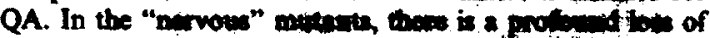

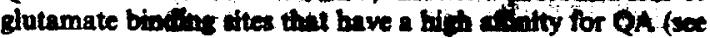
text and Table 1).

binding sites are QA-sensitive. In the moboular layer of MAM-treated mice, QA-cencitive sites were increased to $214 \%$ of control $(P<0.01)$ in repions adjacent to severe granule cell aplation (M4) 2 and 3). QA-sencitive sites were increased to $200 \%$ of control in the GRN of theac mice $(P<0.01)$. In the mice lacking Purkinje cells ("mervous" mutants), there was a marted lose of QA biading was in the molecular layer, where the Purtinge call dudtites are located (Figs 2 and 3). QA-senitive binding sites measured as glutamate binding in the presence of $100 \mu \mathrm{M}$ NMDA, showed a reduction to $29 \%$ of control in the molecular hyer $(P<0.001) ; Q A$ wites were unchanged in the ORN of twose mico. Sinethrly, detailed QA competition curver, anatyeod by an iterative curve-stting computer proprene," hownod that QA binding sites were decreated to $27 \%$ of control $(P<0.005)$ in the molwowiter tayer of "nervous" mutants (Fig. 5 and Table 1).

\section{N-Methyl-D-aspartate-sensitipe binding stites}

There were more NMDA-semitive binding sited in

Table 1. Comparicon of quinguelate biading paramoters in control mice and mice

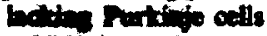

\begin{tabular}{lcccc}
\hline & $K_{H}$ & $K_{L}$ & $R_{H}$ & $\begin{array}{c}R_{L} \\
(\text { pmol/mg protein) }\end{array}$ \\
\hline Control & $114 \pm 60$ & $175 \pm 64$ & $25 \pm 1$ & $7 \pm 1$ \\
Nervous & $25 \pm 6$ & $53 \pm 45$ & $6 \pm 3$ & $7 \pm 2$ \\
\hline
\end{tabular}

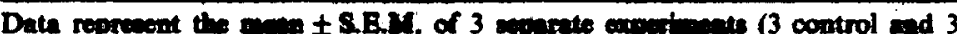

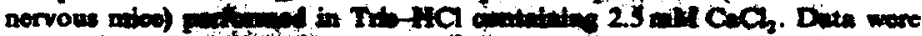

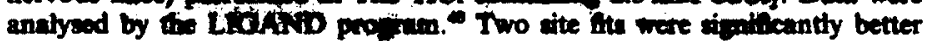
than one site fits in all caves. $P<0.005$ by unpaind $t$-tent. 


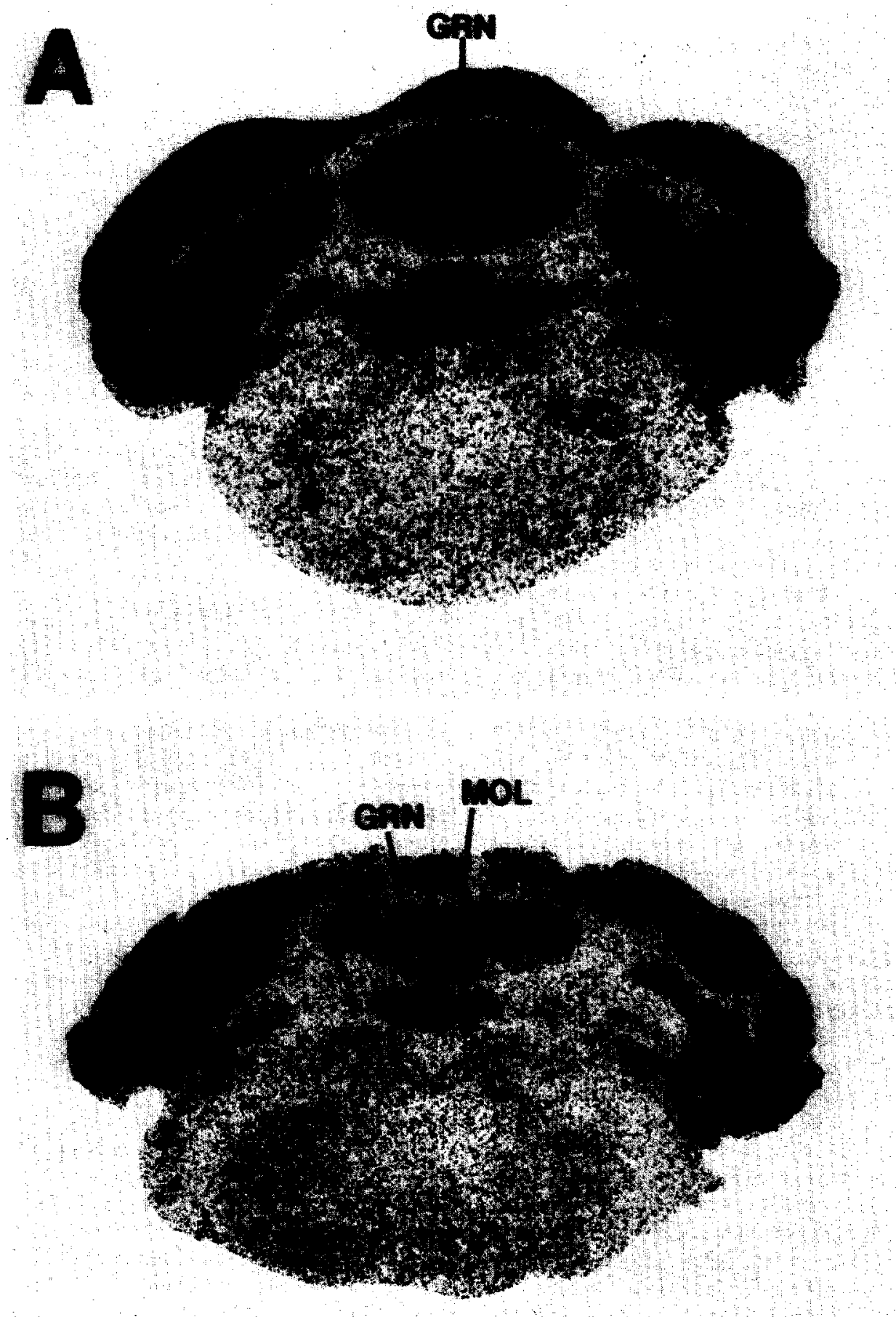

Fig. 6. Autoradiographs of kainate binding in control cerebellum (A) and granule cell-deficient cerebellum (B). Control mice have more KA binding in the GRN than in the molecular layer. In mice lacking granule cells, KA binding is reduced in the GRN and unchanged in the molecular layer (see text and Fig. 3D), MOL, molecular layer.

the GRN than in the molecular layer of control mice (3.57 vs $1.58 \mathrm{pmol} / \mathrm{mg}$ protein, respectively) (Figs 2 and 3). In the GRN of MAM-treated mice, NMDAsensitive binding sites were decreased to $47 \%$ of control $(P<0.001)$ (Figs 2 and 3). NMDA sites were also decreased to $62 \%$ of control $(P<0.001)$ in the molecular layer of MAM-treated mice (Figs 2 and 3). Mice lacking Purkinje cells had normal levels of NMDA binding sites in both GRN and the molecular layer (Figs 2 and 3). 


\section{Kainate receptors}

KA binding sites, assayed with $\left[{ }^{3} \mathrm{H}\right] \mathrm{kainate}$, were more dense in GRN than in the melecular layer in normal mouse cerebellum ( 1.22 vs $0.65 \mathrm{pmol} / \mathrm{mg}$ protein, respectively) (Fig. 6). MAM treatment did not affect KA binding in the molecular layer but decreased the number of sites to $49 \%$ of control in the GRN $(P<0.01)$. KA binding sites were not assayed in the "nervous" mutants lacking Purkinje cells.

\section{DISCUSSION}

The cerebellar cortex is a relatively uniform, laminar structure contain five intrinsic neuronal typesgranule, Purkinje, Golgi, stellate and basket cellswhich are arranged in three distinct layers. ${ }^{29,41}$ The deepest layer, the GRN, consists of numerous, densely packed granule cell bodies and dendrites and less common Golgi cell bodies. The middle layer, situated just outside the GRN, is compcsed of a single layer of Purkinje cell bodies. The andritic arbor of the Purkinje cells is located in the most superficial layer, the molecular layer. Axons of the granule cells project from the GRN into the molecular layer and there, divide to form the parallel fibers which make extensive synaptic contacts with the Purkinje cell dendrites. The stellate and basket cells and Golgi cell dendrites are also located in the molecular layer and, to a lesser extent, also receive synaptic input from the parallel fibers. The granule cells are the only intrinsic cerebellar cells which are excitatory, ${ }^{29,41}$ and extensive evidence suggests that glutamate is the transmitter of the granuie cell/parallel fiber system. ${ }^{28,45.56}$

Afferents to the cerebellar cortex, the mossy fibers and the climbing fibers, are excitatory. "Recent evidence suggests that the mossy fibers, ${ }^{48}$ and the climbing fibers ${ }^{17.4 .54}$ may also use excitatory amino acid neurotransmitters. Mossy fibers, from brainstem and spinal cord, synapse in the GRN on the dendrites of granule cells. Climbing fibers synapse in the molecular layer on Purkinje cells. Thus, the dendrites of Purkinje cells receive excitatory amino acid input from both the granule cell/parallel fiber system and the climbing fibers while stellate, basket and Golgi cells receive input from the granule cell parallel fiber system only. Similarly, the granule cells receive such input from the mossy fibers. It might be expected, then, that all cerebellar cortical neurons would have binding sites for excitatory amino acids.

The cellular location of excitatory amino acid receptors in mouse cerebellum can be determined by using mice which lack selected cell types. When mice are treated within $24 \mathrm{~h}$ of birth with MAM, the chemical kills dividing granule cells by alkylating nucleic acids. ${ }^{30}$ Stellate, basket and Golgi cells may be involved to a lesser extent. ${ }^{1-3,26.35 .48}$ The resulting cerebellum is hypoplastic, with a marked loss of granule cells and a molecular layer containing disor- ganized Purkinje cells. There is no apparent increase in glial cell number and only slight swelling of their processes despite massive neuronal loss. Except for abnormal orientation, and the possible presence of some aberrant Purkinje cell dendrites in the GRN, Purkinje cells appear entirely normal, with intact postsynaptic dendritic spines. ${ }^{27.31,33,46}$ The dendritic spines of Purkinje cells are the exclusive sites of parallel fiber synapses onto these cells. ${ }^{29,30}$ The net result of this treatment is a relatively selective destruction of glutamatergic granule cells and deafferentation of Purkinje cells which retain normal dendritic spines in the molecular layer. In contrast, "nervous" ( $\mathrm{nr} / \mathrm{nr}$ ) is an autosomal recessive mutation of BALB/cGr inbred mice which results in sclective degeneration of approximately $90 \%$ of Purkinje cells." The use of MAM-treated and "nervous" mutant mice allows determination of the number and type(s) of excitatory amino acid receptors located on non-Purkinje and Purkinje cells, respectively.

\section{Quisqualate-sensitive binding sites}

Approximately $75 \%$ of glutamate binding in the molecular layer of normal mice is associated with binding to QA-sensitive sites, as reported previously. ${ }^{22.24}$ Granule cell/parallel fiber synapses on Purkinje cell dendrites are the most numerous synapse in the molecular layer. ${ }^{27}$ It is therefore possible that the most abundant type of binding site in the molecular layer, the QA binding site, is associated with the type of excitatory amino acid synapse most numerous in this region. In support of this hypothesis that QA binding sites mediate the parallel fiber-Purkinje cell synapse, QA-sensitive binding site data (Fig. 3A) indicate decreased QA-sensitive binding in the absence of Purkinje cells. Because the density of Bergman astrocytes increases in the molecular layer of nervous mice, the observed decrease in binding to this layer could be due to greater absorption of beta emission by glia. ${ }^{21}$ This possibility is unlikely though since there is no change in NMDA binding site density in the molecular layer of these same brains. Thus, QA binding sites appear to be located on Purkinje cells. The remaining QA binding sites in the molecular layer are probably located on the $10 \%$ of Purkinje cells unaffected by this mutation and on remaining basket, stellate and Golgi cells with which the parallel fibers also synapse.

We have also found that when Purkinje cells are deafferented by granule cell ablation in MAM-treated mice, there is an apparent up-regulation of QA binding sites in areas of the molecular layer adjacent to the regions of greatest granule cell ablation. This is consistent with the preservation of normal postsynaptic dendritic spines on the Purkinje cells of MAM-treated mice. ${ }^{27}$ Although we cannot rule out entirely the possibility that this up-regulation merely reflects a relative concentration of Purkinje cell dendrites due to parallel fiber loss, this appears unlikely 
since NMDA binding sites are decreased and kainate binding sites are unchanged by this treatment (see below). It is noteworthy that Slevin et al. ${ }^{48}$ reported a $65 \%$ increase in glutamate binding in mouse cerebellar homogenates following MAM treatment. In addition, physiological evidence for denervation supersensitivity at a central glutamatergic synapse has recently been described. ${ }^{49}$ Binding to QA-sensitive sites in the molecular layer adjacent to areas of the GRN which were not affected by MAM treatment was unchanged from controls (data not shown). This suggests that the increase in binding sites is due to granule cell loss rather than MAM treatment itself. Although the $40 \mu \mathrm{m}$ resolution of this receptor autoradiographic method is insufficient to provide a definite answer, the data from "nervous" and MAMtreated mice suggests that QA binding sites are associated with the parallel fiber-Purkinje cell synapse. The results of physiological and biochemical studies which attempt to mimic the actions of the parallel fiber-Purkinje cell synapse in vivo are consistent with this interpretation. ${ }^{8,9,16}$

QA-sensitive binding sites are also found in the granule cell layer of cerebellar cortex. However, it is unlikely that these sites are associated with granule cells, because granule cell ablation actually leads to an increase in QA sites in the GRN. Most likely this is due to "the presence of aberrant Purkinje cell dendrites among the granule cells" postulated by Lovell and coworkers. ${ }^{33}$ In "nervous" mutant mice QA-sensitive sites were not changed in the GRN. Binding to the QA site is dependent on both calcium and chloride ions. ${ }^{22}$ Recently, a chloride-dependent, quisqualate-sensitive glutamate binding site, possibly a transport site, has been described in astrocyte membranes. ${ }^{5}$ It is unlikely that this site is measured in our assay because binding to the astrocytic site is highly temperature-dependent and no specific binding can be measured at $2^{\circ} \mathrm{C}$, the temperature at which our assay is performed. Also, the QA binding site described in the present study decreases in other regions of glial proliferation such as kainate-lesioned striatum (unpublished observations) or striatum of patients dying with Huntington's disease. ${ }^{23}$ Finally, the affinity of quisqualate for the QA binding site described here is at least 1000 -fold higher than that of the astrocytic site. ${ }^{5}$

It should also be noted that the QA binding site described in this report is not the 2-amino-4-phosphonobutyrate (AP4)-sensitive glutamate binding site described in fresh homogenates. ${ }^{12,53}$ The AP4sensitive site, which is chloride-dependent and calcium-enhanced, is destroyed by freezing, ${ }^{13,53}$ and is therefore not present in autoradiographic assays. ${ }^{22,39}$ Furthermore, AP4 has no effect on glutamate binding in our assay. 22

In summary, the evidence suggests that the QAsensitive binding site described here is located on neurons, can up-regulate in response to deafferentation, and corresponds to the dendritic QA receptor defined electrophysiologically in the molecular layer of the cerebellum.

\section{$\mathrm{N}$-Methyl-D-aspartate-sensitive binding sites}

In cerebellar cortex, NMDA-sensitive binding sites are more abundant in the GRN than in the molecular layer, as reported previously. $22,24,37$ The bulk of NMDA binding sites in the GRN appear to be associated with granule cell dendrites because MAM treatment results in a $53 \%$ reduction of NMDA sites. These binding sites may be postsynaptic to mossy fibers which, based on immunocytochemical data, may be glutamatergic. ${ }^{4}$ Alternatively, if Golgi neurons are destroyed by MAM treatment then the NMDA sites may be located on Golgi neurons.

In animals treated with MAM there is a reduction in NMDA binding sites in the molecular layer (Fig. 3B). Destruction of stellate and, perhaps, basket cells by MAM in this layer suggests that NMDA binding sites are located on stellate and basket cells. As with NMDA sites in the GRN, the NMDA sites in the molecular layer might be located on Golgi neurons if these cells are destroyed by MAM. Localization of NMDA binding sites to stellate cells and possibly to basket and Golgi cells is in agreement with electrophysiological studies in which NMDA has prominent effects on inhibitory interneurons when applied iontophoretically.,43 Furthermore, the only cells in the cerebellar cortex which are vulnerable to NMDA toxicity are stellate, Golgi, and basket cells. ${ }^{19}$

Another possibility is that a portion of the NMDA sites are located on axon terminals (parallel fibers) of granule cells. In MAM-treated cerebella, there is no change in NMDA binding in the molecular layer adjacent to the GRN in which granule cells were unaffected by MAM. The data demonstrating decreased NMDA-sensitive binding (Fig. 3B) was obtained by densitometrically analysing the molecular layer adjacent to substantial granule cell ablation. Presynaptic NMDA receptors have been postulated in olfactory cortex based on glutamate release studies $^{7}$ and in hippocampus based on electrophysiological studies $^{6}$ and glutamate release. ${ }^{34}$ The present study contains the first binding data suggestive of presynaptic NMDA receptors.

In "nervous" mutant mice lacking Purkinje cells, NMDA binding sites were unchanged in the molecular layer. This provides strong evidence that few, if any, NMDA binding sites are located on the dendrites of Purkinje cells and further strengthens the supposition that QA receptors mediate synaptic transmission of the parallel fibers. Electrophysiological data also suggest that there are few NMDA receptors on Purkinje cells. Crepel et al. ${ }^{9}$ recorded from Purkinje cells during iontophoretic dendritic application of excitatory amino acids and found that NMDA was very weak or inactive in this region, whereas QA was a very potent excitant. 
Kainate-sensitive binding sites

The distribution of KA binding sites in this study is similar to that reported by others, ${ }^{38,50}$ with higher levels of binding found in the GRN than in the molecular layer. KA binding sites were reduced by half in the GRN of MAM-treated mice, indicating that these binding sites are likely associated with granule cell dendrites. KA binding in the molecular layer was unaffected by granule cell ablation. This suggests that there are not presynaptic KA binding sites on parallel fibers and argues against a role for such $\mathrm{KA}$ receptors at granule cell axon terminals in controlling glutamate release. ${ }^{14}$ Future studies, using mice lacking climbing fibers or mossy fibers, may elucidate the site of action of kainate in mediating excitatory amino acid release. The question of whether there are KA binding sites located on Purkinje cells was not addressed in the present study, although there is physiological evidence to this affect. $^{20}$

\section{CONCLUSIONS}

In this study we have used quantitative autoradiography to localize excitatory amino acid binding sites in the cerebellum. We have strengthened the contention that QA binding sites mediate the responses of the parallel fiber-Purkinje cell synapse. Our data further suggest that these binding sites up-regulate in response to deafferentation. We have also provided evidence that a population of NMDA binding sites is located on granule and stellate cells and, perhaps, on basket and Golgi cells. Granule cells also appear to have $\mathrm{KA}$ binding sites. This information should help to better define the roles and sites of action of excitatory amino acids in the cerebellum.

Acknowledgements - This work was supported by National Science Foundation Grant BNS-8118765, United Cerebral Palsy Foundation Grant R-305, USPHS Grant NS 19613, National Institutes of Health Training Grant 020073 (J.M.M.O.) and National Institutes of Mental Health Individual Predoctoral National Research Service Award I F31 MH08922 to J.T.G.

\section{REFENENCES}

1. Altman J. (1972) Postnatal development of the cerebellar cortex in the rat. I. The extermal germinal layer and the transitional molecular layer. J. comp. Neurol. 146, 353-398.

2. Altmen J. and Bayer S. A. (1977) Time of origin and distribution of a new cell type in the rat cerebellar cortex. Expl Brain Res. 23, 265-274.

3. Altman J. and Bayer S. A. (1978) Prenatal development of the cerebellar system in the rat. 1. Cytogenesis and histogenesis of the deep nuclei and the cortex of the cerebellum. J. comp. Newrol. 179, 23-48.

4. Beitz A. J., Larson A. A., Monaghan P., Altchuler R. A., Mullet M. A. and Madl J. E. (1986) Immunohistochemical localization of glutamate, glutaminase and aspartate aminotransferase in neurons of the pontine nuclei of the rat. Neuroscience 17, 741-753.

5. Bridges R. J., Nietro-Sampedro M. and Cotman C. W. (1985) Stereospecific binding of L-glutamate to astrocyte membranes. Sac. Neurosci Abstr. I1, 110.

6. Collingridar G. L., Kohl S. J. and McLonnan H. (1983) Excitatory amino acidis in synaptic transmission in the Schaffer collaterat-comanienural pathway of the rat hippocampus. J. Physiol., Lond. 334 33-46.

7. Collins G. G. S., Anson J. and Surtees L. (1983) Prexynaptic kainate and N-methyl-D-aspartate receptors regulate excitatory amino acid release in the olfectory cortex. Brain Res. 258, 157-159.

8. Crepel F., Dupont J. L. and Gurdette R. (1983) Voltage clamp analysis of the effects of excitatory amino acids and derivatives on Purkinje cell dendrites in rat cerebellir stices maintained in vitro. Broh Res. 279, 311-315.

9. Crepel F. S., Dhanjil S. S. and Soars T. A. (1982) Efioct of glutamate, aspartate and related derivatives on cerebellar Purkinje cell dendrites in the rat: An in vitro study. J. Physiol, Lond. 325, 297-317.

10. Dauth G. W., Frey K. F. and Gilman S. (1984) A densitometer for quantitative autoradiography. J. neurosei. Meth. 9, 243-251.

11. Eocles J., Ito M. and Szentigothai J. (1967) The Cerebellum as a Neuronal Machine. Springer, New York.

12. Fags G. E., Foster A. C., Menn E. E. and Cotman C. W. (1982) Chloride and calcium ions reveal a pharmacologically distinct population of L-glutamate binding sites in synaptic membranes: Correspondence between biochemical and electrophysiolojical data. J. Newerosci. 2, 958-965.

13. Fagg G. E., Mona E. E., Monaghen D. T. and Cotman C. W. (1983) Freezing eliminates a specific population of L-ghutamate receptors in synaptc membranes. Newrosci. Lett. 34, 157-162.

14. Ferkany J. W. and Coyle J. T. (1983) Kainic acid selectively stimulates the release of endogenous excitatory amino acids. J. Pharmac. exp. Ther. 20s, 399-406.

15. Fonnum F. (19s4) Olutamate: A neurotranemiter in mammalian brain. J. Neurochem. $42,1-11$.

16. Foster G. A. and Roberts P. J. (1981) Stimulation of rat cerebeller gusnosine 3',5'-cyclic monophoephate (cyclic GMP) levels: Bffects of amino acid amtaponits. B. J. Pharmac. 74, 723-729.

17. Fotter G. A. and Roberts P. J. (1533) Neurochernieal and pharmseological correlates of inferior olive deatruction in

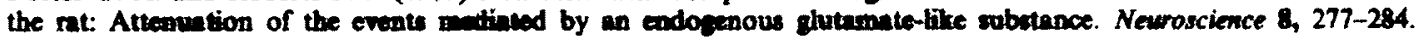

18. Frecanen M. E., Lane J. D. aed Suith J. E. (1983) Turnover rates of amino acid neurotransmitters in regions of rat cerebellum. J. Newroctiem. 14, 141-1447.

19. Garthwaite G. and Garthwaite J. (1984) Diferential sensitivity of rat cerebellar cells in vitro to the neurotoxic effects of excitatory amino acid amalopes. Neurosel. Letr. 4, 361-367.

20. Garthwaite J., Garthwaite G. and Hajb F. (1966) Amino acid neurotoxicity: relationship to neuronal depolarization in rat cerchellar sices. Neweractence if, $49-460$.

21. Geary W. A. III, Toga A. W. and Wooten G. F. (1985) Quantitative film autoradiography for tritium: Methodological considerations. Broin Res. 337, 99-108.

22. Greenamyre J. T., Otson J. M. M., Penney J. B. and Young A. B. (1985) Autoradiographic characterization of $N$-methyl-D-aspartate-, quiequalate- and kainate-sensitive ghutamate binding sites. J. Pharmac. exp. Ther. 223, $254-263$. 
23. Greenamyre J. T., Penney J. B., Young A. B., D'Amato C. J., Hicks S. P. and Shoulson 1. (1985) Alterations in L-[H]glutamate binding in Alzheimer's and Huntington's diseases. Science 227, 1496-1499.

24. Greenamyre J. T., Young A. B. and Penney J. B. (1984) Quantitative autoradiographic distribution of $\mathbf{L}-\left[{ }^{3} \mathrm{H}\right] \mathrm{glutamate}$ binding sites in rat central nervous system. $J$. Neurosci. 4, 2133-2144.

25. Halpain S. H., Wieczorek C. M. and Rainbow T. C. (1984) Localization of L-glutamate receptors in rat brain by quantitative autoradiography. $J$. Neurosci. 4, 2247-2258.

26. Hausmann B., Mangold U., Sievers J. and Berry M. (1985) Derivation of cerebellar golgi neurons from the external granular layer: evidence from explanation of external granule cells in vivo. J. comp. Newrol. $232,511-522$.

27. Hirano A., Dembitzer H. M. and Jones M. (1972) An electron microscopic study on cycasin-induced cerebellar alterations. $J$. Neuropath. exp. Neurol. 31, 113-125.

28. Hudson D. B., Valcans T., Bean G. and Timiras P. S. (1976) Glutamic acid, a strong candidate as the neurotransmitter of the cerebellar granule cell. Neurochem. Res. 1, 73-81.

29. Ito M. (1984) The Cerebellum and Neural Control. Raven Press, New York.

30. Johnston M. V. and Coyle J. T. (1982) Cytotoxic lesions and the development of transmitter systems. Trends Neurosci. $5,1-4$.

31. Jones M. and Gardner E. (1976) Pathogenesis of methylazoxymethanol-induced lesions in the postnatal mouse cerebellum. J. Neuropath. exp. Neurol. 35, 413-443.

32. Landis S. C. (1973) Granule cell heteropia in normal and nervous mutant mice of the BALB/C strain. Brain Res. 61, 175-189.

33. Lovell K. L., Goetting M. G. and Jones M. Z. (1980) Regeneration in the cerebellum following methylazoxymethanolinduced destruction of the external germinal layer. Devl Neurasci. 3, 128-139.

34. Lyach M. A., Errington M. L. and Bliss T. V. P. (1985) Long-term potentiation and the sustained increase in glutamate release which follow tetanic stimulation of the perforant path are both blocked by $D(-)$ aminophosphonovaleric acid. Soc. Neurosci. Abstr. 11, 834.

35. Matsumoto T., Spatz M. and Laqueur G. L. (1972) Quantitative changes with age in the DNA content of methylazoxymethanol-induced microencephalic rat brain. $J$. Neurochem. 19, 297-306.

36. McLennan $H$. (1981) On the nature of the receptors for various excitatory amino acids in the mammalian central nervous system. Adb. Biochem. Psychopharmac. 27, 253-262.

37. Monaghan D. T. and Cotman C. W. (1985) Distribution of $N$-methyl-D-aspartate-sensitive L- $\left.{ }^{3} \mathrm{H}\right]$ glutamate-binding sites in rat brain. J. Neurosci. 5, 2909-2919.

38. Monaghan D. T. and Cotman C. W. (1982) The distribution of $\left[{ }^{3} \mathrm{H}\right] \mathrm{kainic}$ acid binding sites in rat $\mathrm{CNS}$ as determined by autoradiography. Brain Res. 252, 91-100.

39. Monaghan D. T., Holets V. R., Toy D. R. and Cotman C. W. (1983) Anatomical distributions of four pharmacologically distinct ${ }^{3} \mathrm{H}-\mathrm{L}-$ glutamate binding sites. Nature 306, 176-179.

40. Munson P. J. and Rodbard D. (1980) Ligand: A versatile computerized approach for characterization of ligand-binding systems. Analyt. Biochem. 107, 220-239.

41. Palay S. L. and Chan-Palay V. (1974) Cerebellar Cortex Cytology and Organization. Springer, New York.

42. Pan H. S., Frey K. A., Young A. B. and Penney J. B. Jr (1983) Changes in [ ${ }^{3}$ H]muscimol binding in substantia nigra, entopeduncular nucleus, globus pallidus, and thalamus after striatal lesions as demonstated by quantitative receptor autoradiography. J. Neurosci. 3, $1189-1193$.

43. Quinlan J. E. and Davies J. (1985) Excitatory and inhibitory responses of Purkinje cells, in the rat cerebellum in vivo, induced by excitatory amino acids. Neurosci. Lett. $60,39-46$.

44. Rea M. A., McBride W. J. and Rohde B. H. (1980) Regional and synaptosomal levels of amino acid neurotransmitters in the 3-acetylpyridine deafferented rat cerebellum. $J$. Neurochem. 34, 1106-1108.

45. Sandoval M. E. and Cotman C. W. (1978) Evaluation of glutamate as a neurotransmitter of cerebellar parallel fibers. Neuroscience 3, 199-206.

46. Sanger V., Yang M. and Mickelson O. (1972) Cycasin-induced central nervous system lesions in postnatal mice. Fedn Proc. Am. Socs exp. Biol. 31, 1524-1529.

47. Sidman R. L. and Green M. C. (1970) "Nervous", a new mutant mouse with cerebellar disease. In Les Mutants Pathologiques chez l'Animal Leur Interet dans la Recherche Biomedicale. Center National de la Recherche Scientifique, Paris.

48. Slevin J. T., Johnston M. V., Biziere K. and Coyle J. T. (1982) Methylazoxymethanol acetate ablation of mouse cerebellar granule cells: effects on synaptic neurochemistry. Devl Neurosci. 5, 3-12.

49. Talman W. T. (1985) Modification of dose related responses to L-glutamate microinjection into the nucleus tractus solitarius of rats after degeneration of vagal afferent nerves. Soc. Neurosci. Abstr. 11, 106.

50. Unnerstall J. R. and Wamsley J. K. (1983) Autoradiographic localization of high-affinity [ ${ }^{3} \mathrm{H}$ ] kainic acid binding sites in the rat forebrain. Eur. J. Pharmac. 86, 361-371.

51. Watkins J. C. (1981) Pharmacology of excitatory amino acid receptors. In Glutamate: Transmitter in the Central Nervous System (eds Roberts P. J., Storm-Mathisen J. and Johnston G. A. R.), Pp. 1-24. John Wiley, New York.

52. Watkins J. $C$ and Evans R. H. (1981) Excitatory amino acid neurotransmitters. A. Rev, Pharmac. Toxic. 21, $165-204$.

53. Werling L. L., Doman K. A. and Nadler J. V. (1983) L- $\left[{ }^{3} \mathrm{H}\right]$ Glutamate binding to hippocampal synaptic membranes: Two binding sites discriminated by their differing affinities for quisqualate. J. Neurochem. 41, 586-593.

54. Wiklund L., Toggenburger G. and Cuenod M. (1982) Aspartate: Possible neurotransmitter in cerebellar climbing fibers. Science 216, 78-80.

55. Young A. B. and Greenamyre J. T. (1986) Autoradiographic analysis of L- ${ }^{3} H$-glutamate receptors in mammalian brain. In Quantitative Receptor Autoradiography (eds. Boast C., Snowhill E. W. and Altar C. A.), pp. 79-101. Alan R. Liss, New York.

56. Young A. B., Oster-Granite M. L., Herndon R. M. and Snyder S. H. (1974) Glutamic acid: Selective depletion by viral-induced granule cell loss in hamster cerebellum. Brain Res. 73, 1-13. 